\title{
Molecular Detection of Coxiella burnetii, Rickettsia africae and Anaplasma Species in Ticks from Domestic Animals in Lesotho
}

\author{
Sibonginhlanhla I. C. Mahlobo-Shwabede ${ }^{1, *} \mathbb{C}$, Oliver T. Zishiri ${ }^{1}{ }^{\mathbb{D}}$, Oriel M. M. Thekisoe $^{2}$ \\ and Mabusetsa J. R. Makalo ${ }^{3} \mathbb{D}$ \\ 1 Discipline of Genetics, College of Agriculture, Engineering and Science, University of KwaZulu-Natal, \\ Durban 4000, South Africa; Zishiri@ukzn.ac.za \\ 2 Unit for Environmental Sciences and Management, North-West University, Potchefstroom 2531, South Africa; \\ oriel.thekisoe@nwu.ac.za \\ 3 Department of Livestock Services, Ministry of Agriculture and Food Security, Maseru 100, Lesotho; \\ mabusetsa1930@gmail.com \\ * Correspondence: innocentiamahlobo@gmail.com; Tel.: +27-(31)-260-8616
}

Citation: Mahlobo-Shwabede, S.I.C.; Zishiri, O.T.; Thekisoe, O.M.M.; Makalo, M.J.R. Molecular Detection of Coxiella burnetii, Rickettsia africae and Anaplasma Species in Ticks from Domestic Animals in Lesotho. Pathogens 2021, 10, 1186. https:// doi.org/10.3390/pathogens10091186

Academic Editor: Olivier Sparagano

Received: 8 July 2021

Accepted: 3 September 2021

Published: 14 September 2021

Publisher's Note: MDPI stays neutral with regard to jurisdictional claims in published maps and institutional affiliations.

Copyright: (c) 2021 by the authors. Licensee MDPI, Basel, Switzerland. This article is an open access article distributed under the terms and conditions of the Creative Commons Attribution (CC BY) license (https:/ / creativecommons.org/licenses/by/ $4.0 /)$.

\begin{abstract}
Tick-borne diseases (TBDs) hamper the growth of the livestock sector and impose major constraints for the health and management of domestic animals in the tropic and subtropical regions globally. Currently, there is no scientific report on the presence of zoonotic pathogens transmitted by tick species in Lesotho. This study aimed to identify zoonotic tick-borne pathogens of economic importance from ticks infesting domestic animals in Lesotho using molecular techniques. A total of 322 tick DNA pools were subjected to PCR screening for the presence of zoonotic pathogens and sequenced. The overall prevalence of Anaplasma spp. was 35\% (113/322), with a $100 \%$ infection rate in Rhipicephalus microplus, followed by R. evertsi evertsi (92\%), Hyalomma rufipes and Otobius megnini sharing $50 \%$ and the lowest infection rate was observed in $R$. decoloratus with $40 \%$. The prevalence of Coxiella burnetii, a gram-negative pleomorphic etiological agent of Query fever (Q fever), was $1 \%$ $(2 / 322)$ for all screened samples, with $20 \%$ of $R$. decoloratus and $1 \%$ of $R$. e. evertsi infected. Rickettsia africae was detected from Hyalomma rufipes with a $70 \%$ prevalence. This study provides a baseline knowledge of tick-borne pathogens of medical and veterinary importance in Lesotho and raises awareness of the prevalence of such diseases within the tourism sector as they are mostly affected.
\end{abstract}

Keywords: Anaplasma species; Coxiella burnetii; Lesotho; Rickettsia africae; ticks; coinfection; zoonoses

\section{Introduction}

Tick-borne diseases (TBDs) hamper the growth of the livestock sector and impose major constraints for the health and management of domestic animals in the tropic and subtropical regions globally [1,2]. Ticks are vectors of many diseases in animals and humans worldwide. Pathogens carried and transmitted by ticks include bacteria, protozoa and viruses of medical and veterinary importance [3]. Eighty percent of the world's livestock population is affected by TBDs as they hinder livestock production globally, with severe effects being observed mostly in rural populations where livestock are an essential source of income and food supply [4]. South Africa (SA) is an agro-exporting nation depending mainly on livestock productivity for subsistence [4,5]. In sub-Saharan Africa, tick-borne zoonotic pathogens are endemic, including Anaplasma spp., Coxiella burnetii, Rickettsia spp. and Ehrlichia spp., and the information available is still of concern for these pathogens [6]. The occurrence of livestock as hosts for ticks in SA promotes the widespread occurrence of TBDs [7].

Anaplasmosis is an emerging vector-borne disease that affects domestic animals globally and is known to manifest as acute or non-clinical infection [8]. Granulocytic anaplasmosis (GA) is an infectious multi-organ human and animal disease. Anaplasma phagocytophilum is known as the aetiological agent of anaplasmosis in different host species, that is, humans (HGA agent-human granulocytic anaplasmosis), which is a zoonotic rickettsial 
infection of neutrophils transmitted by ticks [7,9], horses (A. phagocytophilum/Ehrlichia equi) and dogs (A. phagocytophilum) [10]. The aetiological agents are obligate intracellular gramnegative bacterial species [10]. Anaplasma phagocytophilum and Ehrlichia ewingii colonise host granulocytes, whilst E. canis, E. ruminantium and E. chaffeensis colonise mononuclear phagocytes [10]. Clinical anaplasmosis results in loss of milk production and weight loss, while high fever and anorexia are commonly observed in domestic animals [11]. Anaplasma spp., closely related to A. phagocytophilum, have been described in canine blood in SA [12]. Regardless of these reports on pathogens, no true incidence has been properly investigated in southern Africa.

Query fever (Q-fever) is a zoonotic disease that occurs globally, except in New Zealand [13], and it is caused by the obligate intercellular gram-negative bacterium Coxiella burnetii [14]. Coxiella burnetii infects pets in addition to livestock, which is a latent source of infection to humans [7]. This zoonosis is extremely flexible, and the infection can progress from acute and asymptomatic disease to chronic, and meningoencephalitis can occur. Perinatal infection (cattle, sheep and goats) and bronchopneumonia (sheep) [15] have also been ascribed to this pathogen. Query fever is transmitted by a wide array of tick species carrying about $40 \%$ of natural infection and shedding a significant number of viable organisms in their feces [16]. Since C. burnetii can be transmitted via aerosol inhalation, it has been classified under category B as a bioterrorism agent by the Centers for Disease Control and Prevention and the National Institute of Allergy and Infectious Diseases [14,17-19].

Rickettsioses are febrile illnesses caused by intracellular bacteria of the genus Rickettsia [20]. This genus is classified into spotted fever group (SFG) rickettsiae, typhus group (TG) rickettsiae, Rickettsia bellii group and R. canadensis group [21]. The SFG contains three species which are of medical importance in sub-Saharan Africa and have been identified as Rickettsia africae (African tick-bite fever (ATBF)), R. conorii (Mediterranean spotted fever (MSF)) and $R$. aeschlimannii [22-24]. In SA, the tourism industry has been negatively affected by rickettsiosis, even though there are no reported cases among the indigenous people because this disease does not have clinical signs; many clinical cases (infection and illness) have been reported from tourists returning to their home countries after visiting nature game reserves in SA [25]. African tick-bite fever (ATBF) is caused by Rickettsia africae and is mainly transmitted by Amblyomma species which are principal vectors in southern Africa [3]. Domestic animals infected by ATBF show no clinical symptoms of the disease and are intermittently rickettsemic and can be a source of infection for tick species [26].

To date, there is no published scientific report on the presence of zoonotic pathogens transmitted by various tick species in Lesotho. This study aimed to identify zoonotic tickborne pathogens of economic importance in ticks infesting domestic animals in Lesotho using molecular techniques.

\section{Results}

Tick species collected from Lesotho districts were identified morphologically. In total, there were nine tick species from four major genera, namely Haemaphysalis, Hyalomma, Rhipicephalus and Otobius. Tick species identified were Haemaphysalis elliptica, Hyalomma rufipes, Hyalomma truncatum, Otobius megnini, Rhipicephalus appendiculatus, Rhipicephalus decoloratus, Rhipicephalus evertsi evertsi, Rhipicephalus glabroscutatum and Rhipicephalus microplus (Table 1). The overall number of tick species collected from each domestic animal, the gender and life stage of each tick species was documented, although in the current study these parameters were not analysed. Specimens (Ha. elliptica, Hy. truncatum, and $R$. glabroscutatum) were stored in glycerol during sampling, therefore no molecular analysis was performed due to DNA degradation. These specimens were only used for morphological identification purposes. From the overall ticks collected, a total of 322 pooled DNA samples were subjected to PCR amplification to detect the presence of targeted zoonotic pathogens of economic importance. 
Table 1. Abundance and prevalence (\%) of tick species identified in ten districts from Lesotho.

\begin{tabular}{|c|c|c|c|c|c|c|c|c|c|c|c|}
\hline \multirow[b]{2}{*}{ Tick Species } & \multicolumn{10}{|c|}{ Number of Ticks per District } & \multirow{2}{*}{$\begin{array}{l}\text { Total No. of } \\
\text { Ticks }\end{array}$} \\
\hline & $\begin{array}{c}\text { Berea } \\
(\%)\end{array}$ & $\begin{array}{c}\text { Butha-Buthe } \\
(\%)\end{array}$ & Leribe $(\%)$ & $\begin{array}{c}\text { Mafeteng } \\
(\%)\end{array}$ & Maseru (\%) & $\begin{array}{l}\text { Mohale's } \\
\text { Hoek (\%) }\end{array}$ & $\begin{array}{c}\text { Mokhotlong } \\
(\%)\end{array}$ & $\begin{array}{c}\text { Qacha's Nek } \\
(\%)\end{array}$ & Quthing (\%) & $\begin{array}{c}\text { Thaba Tseka } \\
\text { (\%) }\end{array}$ & \\
\hline $\begin{array}{l}\text { Haemaphysalis } \\
\text { elliptica }\end{array}$ & $0(0)$ & $0(0)$ & $0(0)$ & $0(0)$ & $0(0)$ & $0(0)$ & $0(0)$ & $2(100)$ & $0(0)$ & $0(0)$ & 2 \\
\hline Hyalomma rufipes & $3(3.4)$ & $0(0)$ & $0(0)$ & $0(0)$ & $8(9.2)$ & $7(8.0)$ & $0(0)$ & $66(75.9)$ & $3(3.4)$ & $0(0)$ & 87 \\
\hline $\begin{array}{l}\text { Hyalomma } \\
\text { truncatum }\end{array}$ & $0(0)$ & $0(0)$ & 13 (31.7) & $0(0)$ & $6(14.6)$ & $0(0)$ & $0(0)$ & $22(53.7)$ & $0(0)$ & $0(0)$ & 41 \\
\hline Otobius megnini & $0(0)$ & $0(0)$ & $0(0)$ & $38(8.4)$ & $48(10.6)$ & $76(16.9)$ & $0(0)$ & $289(64.1)$ & $0(0)$ & $0(0)$ & 451 \\
\hline $\begin{array}{l}\text { Rhipicephalus } \\
\text { appendiculatus }\end{array}$ & $0(0)$ & $0(0)$ & $0(0)$ & $0(0)$ & $3(100)$ & $0(0)$ & $0(0)$ & $0(0)$ & $0(0)$ & $0(0)$ & 3 \\
\hline $\begin{array}{l}\text { Rhipicephalus } \\
\text { decoloratus }\end{array}$ & $0(0)$ & $4(1.3)$ & $43(14.0)$ & $24(7.8)$ & $190(61.7)$ & $0(0)$ & $33(10.7)$ & $14(4.5)$ & $0(0)$ & $0(0)$ & 308 \\
\hline $\begin{array}{l}\text { Rhipicephalus e. } \\
\text { evertsi }\end{array}$ & $161(7.5)$ & $168(7.8)$ & $647(30.0)$ & $13(0.6)$ & $244(11.3)$ & $190(9.0)$ & $27(1.3)$ & $694(32.2)$ & $5(0.2)$ & $7(0.3)$ & 2156 \\
\hline $\begin{array}{l}\text { Rhipicephalus } \\
\text { glabroscutatus }\end{array}$ & $0(0)$ & $8(18.6)$ & $0(0)$ & $0(0)$ & $3(7.0)$ & $0(0)$ & $0(0)$ & $32(74.4)$ & $0(0)$ & $0(0)$ & 43 \\
\hline $\begin{array}{l}\text { Rhipicephalus } \\
\text { microplus }\end{array}$ & $0(0)$ & $111(52.7)$ & 43 (19.5) & $0(0)$ & $16(7.3)$ & $0(0)$ & $0(0)$ & 45 (20.5) & $0(0)$ & $5(2.3)$ & 220 \\
\hline $\begin{array}{l}\text { Total no. per } \\
\text { district }\end{array}$ & $164(5.0)$ & 291 (6.6) & $746(22.5)$ & $75(2.3)$ & $518(15.6)$ & $273(8.2)$ & $60(1.8)$ & 1164 (35.2) & $8(0.2)$ & $12(0.4)$ & 3311 \\
\hline
\end{tabular}


In this study, a 37\% (121/322) prevalence of zoonotic pathogens from tick species of domestic animals in districts of Lesotho is reported. Zoonotic species of economic importance were detected, namely Anaplasma spp., C. burnetii and R. africae. Of the 322 pooled tick DNA samples, 121 samples were PCR positive for Anaplasma spp, C. burnetii and R. africae (Table 2). The highest prevalence of zoonotic pathogens occurred for Anaplasma spp. (35\%), followed by R. africae ( $2 \%$ ) and the least prevalent was C. burnetii (1\%) (Table 3). The highest overall infection rate was $52 \%$ for ticks collected from goats and the lowest one was $26 \%$ for ticks collected from cattle (Table 3 ).

Table 2. Tick species that tested PCR positive for zoonotic pathogens.

\begin{tabular}{|c|c|c|c|c|c|}
\hline Ticks & $\begin{array}{c}\text { Total No. of Tick Pools } \\
\text { Screened (n) }\end{array}$ & Anaplasma spp. & Coxiella burnetii & $\begin{array}{c}\text { Rickettsia } \\
\text { africae }\end{array}$ & $\begin{array}{c}\text { Total No. of (+ve) } \\
\text { Tick Pools for } \\
\text { Pathogens }\end{array}$ \\
\hline Hyalomma rufipes & 6 & 2 & $*_{-}$ & 3 & 5 \\
\hline Otobius megnini & 8 & 1 & - & - & 1 \\
\hline Rhipicephalus appendiculatus & 1 & - & - & - & - \\
\hline Rhipicephalus decoloratus & 20 & 2 & 1 & - & 3 \\
\hline Rhipicephalus e. evertsi & 280 & 106 & 1 & 3 & 110 \\
\hline Rhipicephalus microplus & 7 & 2 & - & - & 2 \\
\hline Total no. of (+ve) tick samples & 322 & 113 & 2 & 6 & 121 \\
\hline
\end{tabular}

Table 3. Overall infection rates of ticks collected from domestic animals and number of tested and positive tick pools with targeted zoonotic pathogens in Lesotho.

\begin{tabular}{|c|c|c|c|c|c|}
\hline Hosts & $\begin{array}{l}\text { Total No. of Tick } \\
\text { Pools (n) }\end{array}$ & $\begin{array}{l}\text { Anaplasma } \\
\text { spp. }(\%)\end{array}$ & $\begin{array}{c}\text { Coxiella } \\
\text { burnetii }(\%)\end{array}$ & $\begin{array}{l}\text { Rickettsia } \\
\text { africae }(\%)\end{array}$ & $\begin{array}{l}\text { Total No. of Tick Species of } \\
\text { Domestic Animals (\%) }\end{array}$ \\
\hline Cattle & 73 & $16(22)$ & $2(3)$ & $1(1)$ & $19(26)$ \\
\hline Donkeys & 5 & $*_{-}$ & - & - & - \\
\hline Goats & 116 & $59(51)$ & - & $2(2)$ & $61(52)$ \\
\hline Horses & 9 & $2(22)$ & - & $2(22)$ & $4(44)$ \\
\hline Sheep & 113 & $34(30)$ & - & $1(1)$ & $35(31)$ \\
\hline Vegetation & 6 & $2(33)$ & - & - & $2(33)$ \\
\hline $\begin{array}{l}\text { Zoonotic pathogens overall } \\
\text { infection rate }(\%)\end{array}$ & 322 & $113(35)$ & $2(1)$ & $6(2)$ & $121(37)$ \\
\hline
\end{tabular}

*- = negative for the pathogen.

\subsection{Anaplasma Species}

For Anaplasma spp., $88 \%$ of the total samples tested positive and a corresponding band of $250 \mathrm{bp}$ was detected by ethidium bromide agarose gel electrophoresis followed by UV illumination. The DNA of the pathogen was detected in the pools from seven districts, namely Berea, Butha-Buthe, Leribe, Maseru, Mohale's Hoek, Qacha's Nek and Quthing, whereas all the Mafeteng samples were PCR negative. In the Berea district, the infection rate with Anaplasma spp. was as high as $50 \%$ (Table 4). There was a significant difference in prevalence of Anaplasma spp. between tick species at $p \geq 0.103$. The DNA of ticks identified as positive for the bacterium (R. microplus, R. e. evertsi, Hy. rufipes, $O$. megnini and $R$. decoloratus) via PCR were directly sequenced using a portion of the $16 \mathrm{~S}$ rRNA gene. The sequences matched with uncultured Anaplasma species (MN481611; MN317257; MG241117) with identity ranging from $98-100 \%$ and coverage ranging from 92-99\%. The phylogenetic analysis showed that Anaplasma spp. from Lesotho were closely related to other Anaplasma species, three samples were identified as A. capra (LC432124-26), two samples as E. canis (MN9222610; MN227484) and other samples matched with A. platys (MK814421; MK814418; MK814415) (Figure 1). Monophyletic relationship was observed in each clade. Most (51\%) of the positive tick samples were from ticks infesting goats. There was a $100 \%$ infection rate of Anaplasma spp. detected solely in R. microplus, followed by R. e. evertsi with $92 \%$. Hyalomma rufipes and O. megnini shared a $50 \%$ infection rate and $R$. decoloratus had a $40 \%$ prevalence. 
Table 4. Overall infection rates of Anaplasma spp. in ticks from domestic animals and vegetation in Lesotho districts.

\begin{tabular}{|c|c|c|c|c|c|c|c|c|c|}
\hline Study Group & Anaplasma spp. & Berea & Butha-Buthe & Leribe & Maseru & Mohale' s Hoek & Qacha's Nek & Quthing & $\begin{array}{c}\text { Total Screened (+ve) } \\
\text { Samples per Host and } \\
\text { Overall \% }\end{array}$ \\
\hline \multirow[t]{3}{*}{ Cattle } & Total tested & 0 & 45 & 2 & 17 & 4 & 0 & 0 & 68 \\
\hline & No. of (+ve) & 0 & 11 & $*_{-}$ & 5 & - & 0 & 0 & 16 \\
\hline & $\%$ & 0 & 24 & - & 29 & - & 0 & 0 & 24 \\
\hline \multirow[t]{3}{*}{ Goats } & Total tested & 16 & 1 & 50 & 0 & 4 & 45 & 0 & 116 \\
\hline & No. of (+ve) & 10 & 1 & 30 & 0 & - & 18 & 0 & 59 \\
\hline & $\%$ & 63 & 100 & 60 & 0 & - & 40 & 0 & 51 \\
\hline \multirow[t]{3}{*}{ Sheep } & Total tested & 24 & 6 & 50 & 0 & 6 & 27 & 0 & 113 \\
\hline & No. of (+ve) & 10 & - & 19 & 0 & - & 5 & 0 & 34 \\
\hline & $\%$ & 42 & - & 38 & 0 & - & 19 & 0 & 30 \\
\hline \multirow[t]{3}{*}{ Horses } & Total tested & 0 & 3 & 0 & 0 & 1 & 0 & 5 & 9 \\
\hline & No. of (+ve) & 0 & - & 0 & 0 & - & 0 & 2 & 2 \\
\hline & $\%$ & 0 & - & 0 & 0 & - & 0 & 40 & 22 \\
\hline \multirow[t]{2}{*}{ Donkeys } & Total tested & 0 & 0 & 0 & 0 & 5 & 0 & 0 & 5 \\
\hline & No. of (+ve) & 0 & 0 & 0 & 0 & - & 0 & 0 & - \\
\hline \multirow[t]{3}{*}{ Vegetation } & Total tested & 0 & 0 & 0 & 6 & 0 & 0 & 0 & 6 \\
\hline & No. of (+ve) & 0 & 0 & 0 & 2 & 0 & 0 & 0 & 2 \\
\hline & $\%$ & 0 & 0 & 0 & 33 & 0 & 0 & 0 & 33 \\
\hline Total screened & & 40 & 55 & 102 & 23 & 20 & 72 & 5 & 317 \\
\hline (+ve) samples and & & 20 & 12 & 49 & 7 & - & 23 & 2 & 113 \\
\hline overall $\%$ per district & & 50 & 22 & 48 & 30 & - & 32 & 40 & 36 \\
\hline
\end{tabular}




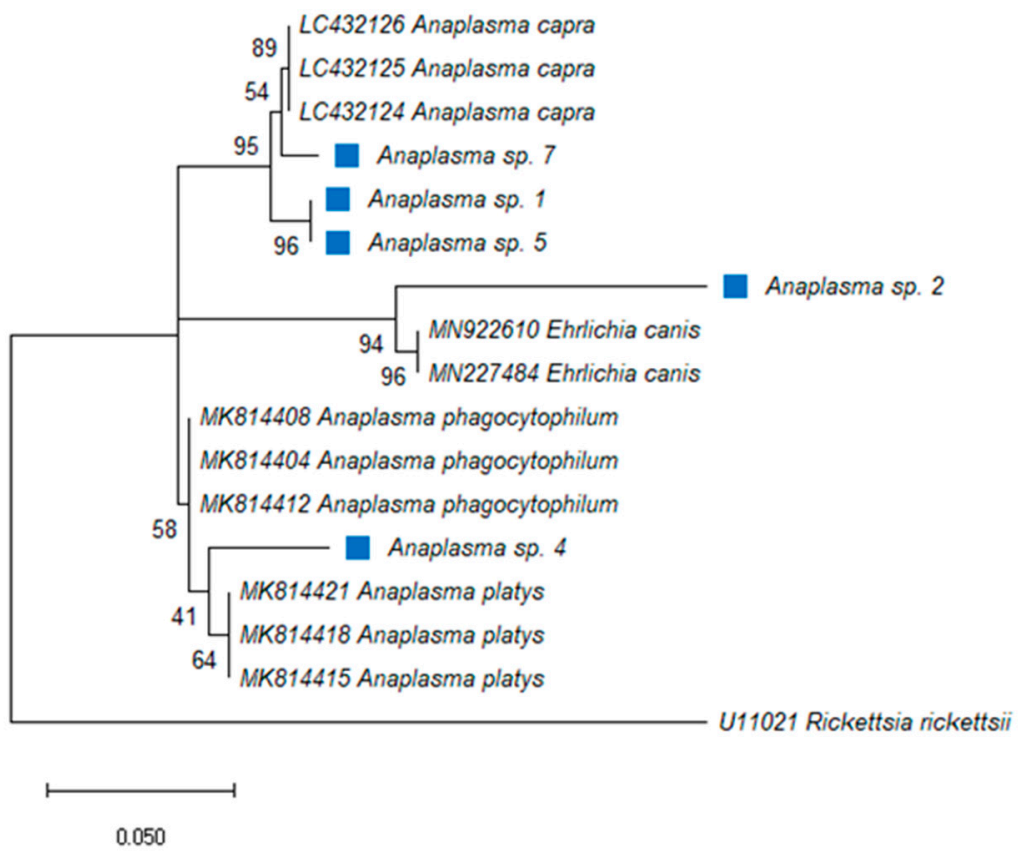

Figure 1. Phylogenetic analysis by Maximum Likelihood (ML) inferred from the 16S rRNA gene, method based on the Kimura 2-parameter model with gamma distributions (+G). The tree highlights the position of Anaplasma and Ehrlichia spp. The blue square indicates Anaplasma spp. identified in this study. Support values (bootstrap replicates of 1000) are indicated at each node of the branch.

\subsection{Coxiella burnetii}

The overall prevalence for $C$. burnetii was $1 \%(2 / 322)$. The infection rate in ticks collected from cattle was $4 \%$ (Table 2). Tick DNA from Butha-Buthe and Mohale's Hoek district were PCR positive for the pathogen with an overall infection rate of $4 \%$ from cattle (Table 5). Of the positive samples, the highest infection rate was $20 \%$ in $R$. decoloratus and $1 \%$ in R. e. evertsi. The difference in C. burnetii prevalence between tick species was highly significant at $p \geq 0.998$. Sequence analysis for the bacterium PCR positive sequenced samples revealed 96\% maximum identity with C. burnetii MT268529-32 and MN025541.

Table 5. Coxiella burnetii overall infection rate (\%) in ticks from cattle in Lesotho districts.

\begin{tabular}{ccccc}
\hline Sampling Site & $\begin{array}{c}\text { Studied } \\
\text { Animals }\end{array}$ & \multicolumn{3}{c}{ Coxiella burnetii } \\
\hline District & Study Group & Positive (+ve) & Total Screened & Overall (\%) \\
\hline $\begin{array}{c}\text { Butha-Buthe } \\
\text { Mohale's Hoek }\end{array}$ & Cattle & 1 & 45 & 2 \\
\hline $\begin{array}{c}\text { Overall } \\
\text { prevalence }\end{array}$ & 1 & 4 & 25 \\
\hline$+\mathrm{ve}=$ positive samples. & 2 & 49 & 4 \\
\hline
\end{tabular}

The amplified PCR product of approximately $687 \mathrm{bp}$ was obtained from C. burnetiipositive ticks. The PCR amplicons from the IS1111 transposase gene were generated from two ticks and sequenced, and DNA sequence analysis revealed that the sequence from $R$. decoloratus in Butha-Buthe and the other from R. e. evertsi in Mohale's Hoek were identical. A C. burnetii sequence was identified from two tick species in this study and was submitted to GenBank and assigned as C. burnetii 26 (MT592821). The 493 nucleotide sequences of the IS1111 transposase gene from 11 bacterial species or isolates belonging to gammaproteobacterial were used to assess the phylogenetic relationships. A member of this class Raoultella ornithinolytica was used as an outgroup species. The phylogenetic 
analysis showed that C. burnetii from this study (designated C. burnetii 26) was closely related to C. burnetii (MT268531) isolated from a tick in Algeria and C. burnetii 26 formed a monophyletic group with other C. burnetii strains, with $100 \%$ identity (Figure 2).

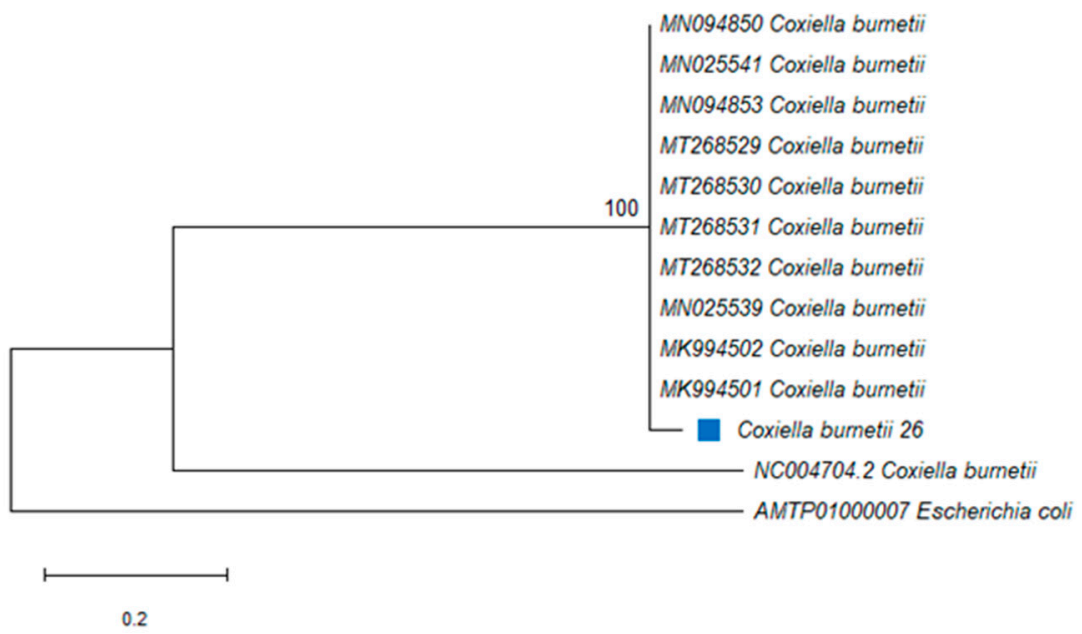

Figure 2. Phylogenetic analysis by Maximum Likelihood (ML) inferred from the IS1111 transposase gene, method based on the Kimura 2-parameter model. The blue square indicates Coxiella burnetii identified in this study. The tree highlights the position of Coxiella burnetii. Support values (bootstrap replicates of 1000) are indicated at each node of the branch.

\subsection{Rickettsia africae}

Rickettsia africae was present in ticks of domestic animals from Berea, Maseru, Qacha's Nek and Quthing, but was absent in ticks collected from Butha-Buthe, Leribe, Mafeteng and Mohale's Hoek (Table 6), having an overall 2\% prevalence of infection. Quthing district had the highest infection rate of $40 \%$. The highest overall infection rate was $22 \%$ in ticks collected from horses, followed by $2 \%$ in ticks from goats and, least shared, $1 \%$ prevalence was in ticks from cattle and sheep (Table 6). Tick species collected from the vegetation and donkeys were PCR-negative for the bacterium (Table 3). The difference in prevalence of $R$. africae between tick species was not significant at $p \geq 0.001$. To confirm the pathogen identity, the gltA gene was sequenced revealing a 99\% identity with $R$. africae gltA gene partial sequences for all the PCR positive samples (Accession number: MG515012, MH751467 and MH737559). Most of the positive samples (75\%) were from Hy. rufipes, while 3\% were detected in $R$. e. evertsi. The O. megnini, R. appendiculatus, R. decoloratus and $R$. microplus pools were negative for the presence of $R$. africae. The sequence of the amplified PCR product of the $R$. africae glt A gene was aligned and compared with other corresponding reference sequences in GenBank. The DNA sequences of $R$. africae from R. e. evertsi were submitted to GenBank and assigned as R. africae 27 (MT585813) and $R$. africae 29 (MT585814), respectively. The Maximum Likelihood (ML) phylogenetic tree of $R$. africae inferred from the partial sequence of the gltA gene indicated that $R$. africae 27 (MT585813) and R. africae 29 (MT585814) were 73\% identical to other isolates of R. africae and were grouped together and closely related to $R$. africae (MH751467) from SA, R. africae (MF737559) from SA and R. africae (MG515012) from Brazil (Figure 3). 
Table 6. Overall infection rates of Rickettsia africae in ticks from domestic animals in Lesotho districts.

\begin{tabular}{|c|c|c|c|c|c|c|c|c|c|}
\hline Study Group & Rickettsia africae & Berea & Butha-Buthe & Leribe & Maseru & Mohaleshoek & Qacha's Nek & Quthing & $\begin{array}{l}\text { Overall \% (+ve) } \\
\text { per Population }\end{array}$ \\
\hline \multirow[t]{2}{*}{ Cattle } & Total tested & 0 & 45 & 2 & 17 & 4 & 0 & 0 & 68 \\
\hline & No. of (+ve) & 0 & 0 & $*_{-}$ & 1 & - & 0 & 0 & 1 \\
\hline \multirow[t]{3}{*}{ Goats } & Total tested & 16 & 1 & 50 & 0 & 4 & 45 & 0 & 116 \\
\hline & No. of (+ve) & 1 & - & - & 0 & - & 1 & 0 & 2 \\
\hline & $\%$ & 6 & - & - & 0 & - & 2 & 0 & 2 \\
\hline \multirow{2}{*}{ Sheep } & No. of (+ve) & 1 & - & - & 0 & - & - & 0 & 1 \\
\hline & $\%$ & 4 & - & - & 0 & - & - & 0 & 1 \\
\hline \multirow[t]{3}{*}{ Horses } & Total tested & 0 & 3 & 0 & 0 & 1 & 0 & 5 & 9 \\
\hline & No. of (+ve) & 0 & - & 0 & 0 & - & 0 & 2 & 2 \\
\hline & $\%$ & 0 & - & 0 & 0 & - & 0 & 40 & 22 \\
\hline Total screened & & 40 & 55 & 102 & 17 & 15 & 72 & 5 & 306 \\
\hline Overall (+ve) samples & & 2 & - & - & 1 & - & 1 & 2 & 6 \\
\hline Overall $\%$ per district & & 5 & - & - & 3 & - & 1 & 40 & 2 \\
\hline
\end{tabular}




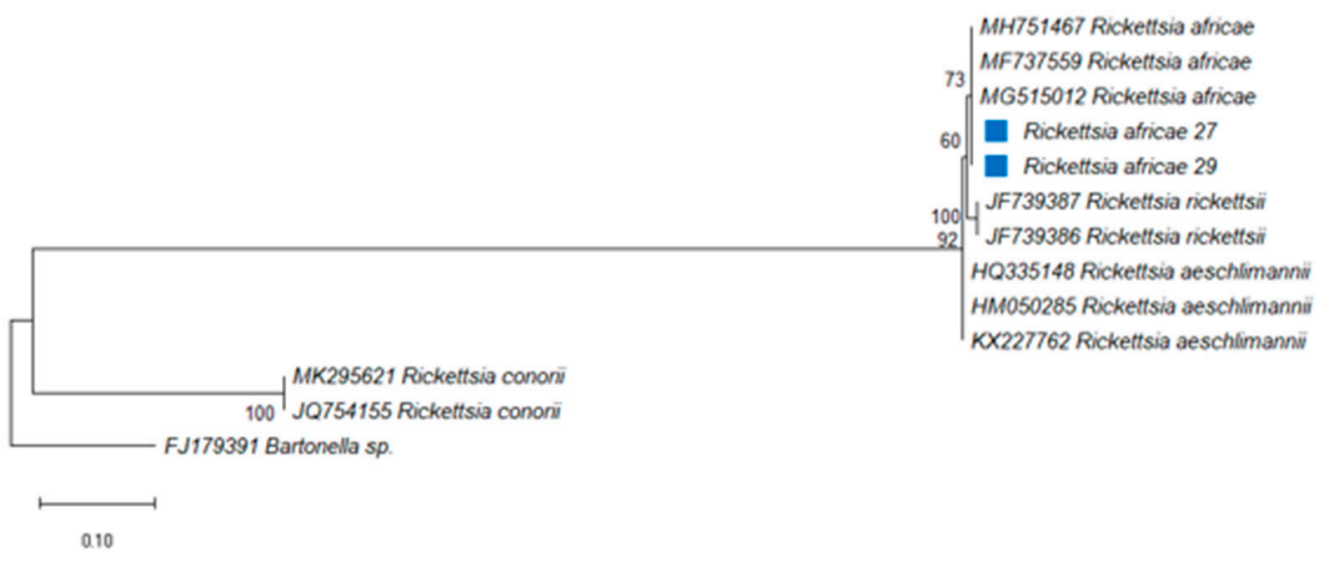

Figure 3. Phylogenetic analysis by Maximum Likelihood (ML) inferred from the gltA gene, method based on the Tamura 3-parameter model. The tree highlights the position of Rickettsia africae. The blue square indicates Rickettsia africae identified in this study. Support values (bootstrap replicates of 1000) are indicated at each node of the branch.

Coinfection was observed among zoonotic pathogens and with piroplasms that were detected in the same tick pools in a previous study, in ticks collected from cattle, goats, horses and vegetation (Table 7). Coinfection with Anaplasma spp. and R. africae were detected in R. e. evertsi and Hy. rufipes with rates of $1 \%$ and $11 \%$, respectively. The coinfection rate ranged between 7-17\% for Anaplasma spp. and Babesia bigemina in R.e. evertsi and $R$. decoloratus, respectively. Additionally, three pathogen coinfections were detected for Anaplasma spp., B. motasi and B. ovis in R. e. evertsi, with a $2 \%$ infection rate. The bivariate correlation test (data not shown) was not significant for the prevalence of zoonotic pathogens (Anaplasma spp. and R. africae) and those of piroplasms (B. motasi and B. ovis) coinfection (Table 7).

Table 7. Coinfection among zoonotic pathogens and other hemoparasites as reported in the literature.

\begin{tabular}{cccccc}
\hline \multirow{2}{*}{ Coinfections } & Pathogens & \multicolumn{3}{c}{ Prevalence N (\%) } \\
\cline { 3 - 5 } & & Cattle & Goats & Horses & Vegetation \\
\hline Two pathogens & Anaplasma spp. + R. africae & $*_{-}$ & $1(1 \%)$ & $1(11 \%)$ & - \\
Three pathogens & Anaplasma spp. + Babesia motasi + B. ovis & - & - & - & $1(17 \%)$ \\
\hline
\end{tabular}

\section{Discussion}

Control measures for most tick species is problematic as they live in close association with vertebrate hosts or in areas that are not easily accessible for acaricides application. Acaricides used to control vectors are not reliable. Currently, there are only two control methods used by farmers where tick species were collected: (1) For small stock, annual dipping, and government initiative campaigns on other injectable antiparasitic; (2) Injectable/pour-on antiparasitic, hand picking and rotational grazing for all the species.

As the first scientific publication on tick-borne pathogens, this study aimed to ascertain by molecular analysis the prevalence of tick-borne microorganisms of zoonotic importance in Lesotho. Species-specific PCR assay used were positive for pathogens detected from various tick species collected from domestic animals. Pathogens of economic importance, namely Anaplasma spp., C. burnetii and R. africae, were identified in ticks of domestic animals and vegetation in Lesotho. Furthermore, zoonotic bacteria, namely Anaplasma spp., C. burnetii and R. africae detected from R. decoloratus and R. e. evertsi, were confirmed through phylogenetic analysis, respectively. 
In SA, Hy. rufipes, R. decoloratus, R. e. evertsi and R. microplus are common tick species with high prevalence and distribution $[27,28]$. O. megnini species have also been collected from cattle in the Eastern Cape, SA [29]. Hyalomma rufipes is a vector of the Crimean-Congo haemorrhagic fever virus [28] and $R$. decoloratus has been reported as a vector of Babesia bigemina in SA, which causes African redwater and Anaplasma marginale, a causative agent of gall sickness in cattle [30-32]. This tick is considered as one of the significant indigenous tick species harbored by cattle [31], while $R$. microplus is a competent vector of both $B$. bigemina and B. bovis, a causative agent of Asiatic redwater which is more virulent $[30,32]$. Rhipicephalus e. evertsi transmits $B$. caballi and Theileria equi, causative agents of equine piroplasmosis, and it also transmits $A$. marginale [27]. Thus far, O. megnini is not known to transmit any pathogen [33].

Anaplasma spp. infections were detected from tick species collected from cattle (22\%) horses $(22 \%)$, goats $(51 \%)$, sheep $(30 \%)$ and vegetation $(33 \%)$. This pathogen has been detected in SA from ticks collected from dogs. This pathogen was identified and characterised through microscopic analysis of a blood sample from a dog in Bloemfontein, SA, by Inokuma [12], but the phylogenetic analysis showed that the pathogen differed significantly from A. phagocytophilum [34]. When compared to data collected in SA, the infection rate by this pathogen was lower, $17 \%$ in goats, $6 \%$ in cattle and $1.25 \%$ in sheep [5]. These findings indicate a clear existence of Anaplasma spp. in Lesotho with a higher than previously reported infection rate among the ticks infesting domestic animals.

Although we report the presence of Anaplasma spp. in ticks from domestic animals, further genetic characterisation needs to be conducted as sequences obtained in this study matched with uncultured Anaplasma species from the blood of cattle. The 16S rRNA gene used in this study did not provide sufficient findings in confirming the true existence of $A$. phagocytophilum; the phylogenetic analysis showed that the pathogen detected was from the genus Anaplasma. However, the species varied significantly. The obtained results do provide a baseline for the presence of Anaplasma pathogens in Lesotho and more studies must be conducted in the future to identify species of the genus Anaplasma that occur in this country using other assays. According to Mtshali [7], Ixodes species are vectors known to transmit this pathogen to humans causing HGA, but this vector is absent in SA which explains the lack of reported cases of this disease. Therefore, Hy. rufipes, R. decoloratus, R. e. evertsi and $R$. microplus should be considered as vectors that transmit Anaplasma spp. in Lesotho. Notably, O. megnini was also PCR positive for Anaplasma spp. and this is the first report to document likely transmission of the pathogen to a host by this soft tick. Otobius megnini adult soft ticks do not feed; only the larvae and nymphal developmental stages are considered to be parasitic [33]. Therefore, more investigation should be conducted in understanding the role of this tick in transmitting or harbouring pathogens.

Interestingly, double, and triple bacterial coinfections were detected in ticks from domestic animals with Anaplasma spp. as a common bacterium in all multiple infections. The coinfection of zoonotic pathogens was detected from Hy. rufipes and R. e. evertsi collected from Quthing horses and Berea goats, respectively. These tick species were infected with $R$. africae and Anaplasma spp., although the infection rate was minimal. Piroplasms and zoonotic bacteria coinfections were detected in R. e. evertsi from Maseru ticks collected from cattle and vegetation, and Mafeteng ticks infesting on cattle were infected with a piroplasm parasite, Babesia bigemina. Additionally, concomitant infections were observed with Anaplasma spp., B. bigemina and B. ovis in ticks from Leribe goats. However, the rate of infection with three different parasites was minimal in R. e. evertsi.

Coxiella burnetii is well known and has been reported throughout the African continent [35]. In West African countries, this pathogen has been identified through serology reports from Amblyomma variegatum, Rhipicephalus senegalensis and Hyalomma truncatum [7,36]. In SA, the infection caused by C. burnetii has been significantly demonstrated solely based on serological methods in cattle, goats and sheep, but recently Mtshali [5] identified the presence of C. burnetii from tick species infesting domestic animals in SA (Free State and KwaZulu-Natal) using molecular methods. 
In this study we report a very low overall infection rate of $4 \%$ in ticks collected from cattle, while ticks collected from goats and sheep had no infection. These findings are corroborated by data from Mtshali [5] where the low incidence of 3\% from cattle ticks, 6\% from goats and 32\% from sheep in SA was observed. In the early 1950s, Gummow [37] claimed that Q-fever levels are kept below a certain threshold within domestic animals, in particular cattle, in SA due to the low incidence considering the C. burnetii endemic stability. However, the bacterium incidence is still not well established and is still underestimated [7]. Additionally, Qiu [38] detected Q-fever and the infection rate was 7.8\% for the overall ticks infesting domestic animals in Zambia; these findings are in line with this current study. Although the infection rates in ticks were low in tick species, this pathogen occurs in Lesotho. It can be ascertained if blood samples are studied.

Eight percent of C. burnetii seroprevalence from cattle has been reported in Transvaal, SA [39]. One human case was reported in Cape Town, where C. burnetii was found to be a cause of pneumonia in the 92-patient cohort [39]. No human reports have been documented recently in SA, suggesting that zoonotic pathogens are not well studied. Additionally, there are limited studies conducted on tick species that can be potential vectors transmitting zoonotic pathogens. Pets have been occasionally reported as the source of human infection of Q-fever as the pathogen can be easily shed by domestic animals. The environment can be contaminated from urine and faeces excreted by infected animals [5]. Therefore, due to a multitude of sources, the potential for human acquisition (including tick bites) are high [7]. In SA to date, the relationship between the bacteria and their pathogenicity to humans, and their prevalence, is unknown $[7,40]$.

In this study, C. burnetii was identified for the first time in $R$. decoloratus collected from cattle, although C. burnetii has been reported from domestic animals in SA but not from vegetation [5], as in this study. Sequence analysis of the IS1111 gene from the genotype of $C$. burnetii detected in ticks revealed a close relationship to C. burnetii (MT268532), identified from (Hyalomma dromedarii) in Algeria, Africa. Coxiella burnetii identified in this study from R. e. evertsi was closely related to C. burnetii (MT268532; Hy. dromedarii), sharing at least $96.75 \%$. The phylogenetic analysis confirms the bacterium identified as C. burnetii, a causative agent of human infection. If this pathogen is identified from a tick, as in this study, it can likely occur in humans through tick bites rather than from an infected animal shedding the bacteria.

In sub-Saharan Africa and in rural settings, R. africae is transmitted by Amblyomma hebraeum [41]. Seroprevalence of ATBF (70\%) has been documented in areas where $A$. hebraeum and cattle coincide. In Mpumalanga, SA, 24.5\% of serological evidence (IgM antibodies) of ATBF in patients with febrile illness has been documented while, within the same community, $92.2 \%$ of patients were seropositive showing common exposure to ATBF rickettsiae [41]. Other cases reported on ATBF have been from people who visited SA as tourists [42]. Two percent of $R$. africae overall infection prevalence was observed in this study from four districts, namely Maseru, Berea, Qacha's Nek and Quthing. In this investigation, the bacterium was isolated from R. e. evertsi and Hy. rufipes collected from cattle, goats, sheep, and horses. These tick species are well distributed in SA [27,28], but the knowledge of biological transmission of $R$. africae to humans is unknown while A. hebraeum is well documented, with $75 \%$ potential in transmitting the pathogen [7]. In this study, Amblyomma species were not collected, and based on these findings, it is likely that animals were intermittently rickettsiemic, so tick infection can be passive other than of the known vector, especially in rural areas where there is close contact between humans and animals. 
The sequence analysis of the gltA gene revealed that ticks from Lesotho domestic animals were infected with $R$. africae. To our knowledge, this is the first report in which $R$. africae was detected in R. e. evertsi and Hy. rufipes in Lesotho and the first report of $R$. africae infection rate in the country. The ML phylogenetic analysis showed that $R$. africae 27 (MT585813) and R. africae 29 (MT585814) both identified in R. e. evertsi grouped with R. africae (MG515012; MF737559; MH751467) from Brazil and two from SA, respectively, confirming that the bacteria isolated was indeed $R$. africae. The results also revealed that $R$. africae in this study were most closely related to $R$. rickettsii, a sister clade that is recognised as a zoonotic pathogen in SFG rickettsiae. The pathogenicity of $R$. africae isolated from $R$. e. evertsi from Lesotho should be studied further to map the prevalence of this zoonotic disease in domestic animals through blood samples.

Interestingly, in this study, the SFG rickettsiae identified in $R$. e. evertsi that were collected from cattle and goats were genetically similar to R. africae (MG515012; MF737559) identified from human skin in Brazil and SA, respectively [43]. The strain isolated from Brazil was originally from a tourist who visited SA. Sequence analysis of the R. africae gltA gene isolated from ticks in this study indicates that the sequences shared $100 \%$ identity. These findings suggest that $R$. e. evertsi can serve as a vector for $R$. africae to humans. Rhipicephalus species role in pathogen transmission is not yet clear, and their infection may depend on coincidental transmission by other recognised vectors such as A. hebraeum [44].

Rhipicephalus species can be considered potential vectors for many tick-borne pathogens, including bacteria and protozoa [45]. However, more robust studies need to be conducted to confirm such and to further understand the mechanism and lifecycle of the pathogen.

This study we recorded two confirmed ticks, namely $R$. decoloratus and $R$. e. evertsi, that were infected with $C$. burnetii and $R$. africae zoonotic pathogens and Anaplasma spp. pathogens detected from Hy. rufipes, $R$. decoloratus, $R$, e. evertsi, $R$. microplus and O. megnini. More robust genetic studies are needed to have better insight into the epidemiology of Anaplasma spp., C. burnetii and R. africae infections in tick species of Lesotho and the mode of transmission on domestic animals. Furthermore, other tick species must be considered as possible ideal vectors of zoonotic pathogens in the absence of well-documented vectors. The use of blood samples to confirm the infection of domestic animals in Lesotho is necessary and may be considered especially for the Anaplasma spp. with the use of more assays.

\section{Materials and Methods}

\subsection{Tick Samples and Identification}

A total of 3311 individual ticks were collected during hot and wet seasons from December 2016 to May 2019 from domestic animals and vegetation. The specimens were collected from ten Lesotho districts, namely Berea, Butha-Buthe, Leribe, Mafeteng, Maseru Mohale's Hoek, Mokhotlong, Qacha's Nek, Quthing and Thaba Tseka (Figure 4). 


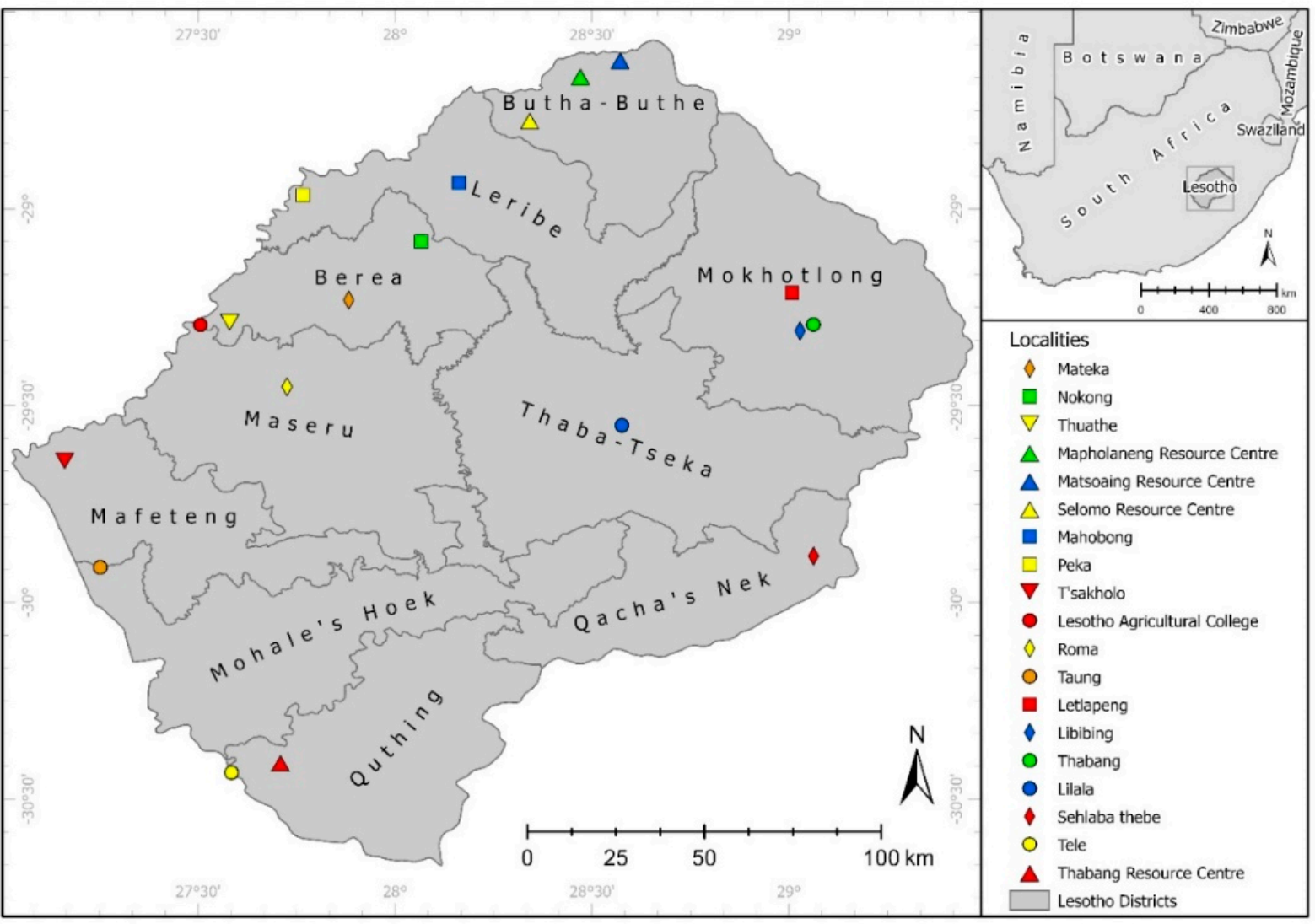

Figure 4. Map of Lesotho. Study area including the ten districts where sampling was carried out.

A total of 1683 ticks from the overall individuals collected were used for molecular analysis. Ticks were collected randomly from cattle, donkey, horses, goats, and sheep (Table 8), focusing on body parts that were severely infested (ears, neck, abdominal and perineum areas). Sterile fine-tipped forceps were used to detach the tick from the host. Questing ticks were collected on vegetation from inactive animal trails (Supplementary Table S1). Specimens were preserved in $70 \%(v / v)$ ethanol and subsequently identified morphologically using taxonomic keys Latif [46], Madder [47] and Walker [48]. Thereafter, representatives of each identified species were confirmed by a tick taxonomist at the Onderstepoort Veterinary Institute. The developmental stage and the sex of each tick species was recorded for each district sampled (Table 9). 
Table 8. Total number of tick species collected from domestic animals and vegetation in each sampled district in Lesotho. Quthing had the lowest samples.

\begin{tabular}{|c|c|c|c|c|c|c|c|c|c|c|c|c|}
\hline \multirow{2}{*}{$\begin{array}{l}\text { Country } \\
\text { Lesotho }\end{array}$} & \multicolumn{12}{|c|}{ Districts } \\
\hline & Hosts & Berea & Butha-Buthe & Leribe & Mafeteng & Maseru & $\begin{array}{c}\text { Mohale's } \\
\text { Hoek }\end{array}$ & Mokhotlong & $\begin{array}{c}\text { Qacha's } \\
\text { Nek }\end{array}$ & Quthing & $\begin{array}{l}\text { Thaba } \\
\text { Tseka }\end{array}$ & $\begin{array}{c}\text { Total per } \\
\text { Host }\end{array}$ \\
\hline & Cattle & $*_{-}$ & 257 & 177 & 75 & 333 & 97 & 43 & 331 & - & 9 & 1322 \\
\hline & Dogs & - & - & 3 & - & - & - & - & 70 & - & - & 73 \\
\hline & Donkeys & - & - & - & - & - & 12 & - & - & - & - & 12 \\
\hline & Goats & 67 & 18 & 219 & - & - & 15 & 7 & 141 & - & 3 & 470 \\
\hline & Horses & - & - & 3 & - & - & 30 & - & 88 & 8 & - & 129 \\
\hline & Sheep & 97 & 12 & 335 & - & - & 119 & 10 & 170 & - & - & 743 \\
\hline & Vegetation & - & 4 & 9 & - & 185 & - & - & 364 & - & - & 562 \\
\hline $\begin{array}{l}\text { Total per } \\
\text { district }\end{array}$ & & 164 & 291 & 746 & 75 & 518 & 273 & 60 & 1164 & 8 & 12 & 3311 \\
\hline
\end{tabular}

Table 9. Sex and development stages of tick specimens identified for each district sampled.

\begin{tabular}{|c|c|c|c|c|c|c|c|c|c|c|c|}
\hline $\begin{array}{l}\text { Gender } \\
\text { and Stage }\end{array}$ & Berea & Butha-Buthe & Leribe & Mafeteng & Maseru & Mohale's Hoek & Mokhotlong & Qacha's Nek & Quthing & Thaba Tseka & $\begin{array}{l}\text { Total (Gender } \\
\text { and Stage) }\end{array}$ \\
\hline Male Adult & 101 & 118 & 232 & 12 & 116 & 81 & 23 & 239 & 5 & 7 & 934 \\
\hline Female Adult & 63 & 119 & 442 & 14 & 205 & 94 & 29 & 424 & 3 & 5 & 1398 \\
\hline Total (district) & 164 & 291 & 746 & 75 & 518 & 273 & 60 & 1164 & 8 & 12 & 3311 \\
\hline
\end{tabular}




\subsection{DNA Extraction from Ticks}

Ticks were pooled (one to four specimens) with specificity to species sex, life stage, host, vegetation and district. All specimens were surface sterilised twice with $70 \%$ ethanol and washed twice with sterile water, ensuring that all debris and animal hairs were removed before being crushed in 1.5 mL Eppendorf ${ }^{\circledR}$ tubes. The genomic DNA (gDNA) was extracted using the Zymo tissue DNA extraction kit following the manufacturer's protocol (Zymo Research Corporation, Irvine, CA, USA) and stored at $-20^{\circ} \mathrm{C}$ until used.

\subsection{Detection of Zoonotic Pathogens DNA by PCR}

The pooled tick DNA was subjected to PCR amplification using oligonucleotide sequences listed in Table 10. The samples were screened for the presence of A. phagocytophilum, C. burnetii and R. africae. Positive controls for C. burnetii and R. africae were obtained from the Research Center for Zoonosis Control (CZC), Hokkaido University, Japan, and from the School of Medicine, Johns Hopkins University, Maryland. The positive control of A. phagocytophilum was obtained from blood collected from a Northern Cape horse in a study by Mlangeni [49]. For all reactions, $\mathrm{ddH}_{2} \mathrm{O}$ was used as a negative control. The infection rate was analysed by PCR methods using species-specific primers to detect zoonotic tick-borne pathogens. Coinfection among zoonotic pathogens and other parasites [50] was tested. The PCR reactions were performed in a $25 \mu \mathrm{L}$ volume with $12.5 \mu \mathrm{L}$ DreamTaq PCR Master Mix (Thermo Fisher Scientific, South Africa), $3 \mu \mathrm{L}$ of each primer (10 $\mu \mathrm{M}$ each primer), $3 \mu \mathrm{L}$ of genomic DNA template and $3.5 \mu \mathrm{L}$ deionised water $\left(\mathrm{ddH}_{2} \mathrm{O}\right)$ was added to the final volume. All PCR reactions were performed using BIO-RAD T100 thermocycler (BIO-RAD Laboratories, South Africa). PCR conditions were as follows: pre-cycle denaturation at 95 ${ }^{\circ} \mathrm{C}$ for $10 \mathrm{~min}$, followed by 35 cycles at $95^{\circ} \mathrm{C}$ for $30 \mathrm{~s}$, annealing (Table 10) for $30 \mathrm{~s}$, extension at $72{ }^{\circ} \mathrm{C}$ for $1 \mathrm{~min}$ and $30 \mathrm{~s}$ and a final extension at $72{ }^{\circ} \mathrm{C}$ for $7 \mathrm{~min}$. PCR product detection was conducted on a $1.5 \%$ agarose gels stained with ethidium bromide and visualised under UV transilluminator electrophoresis, ChemiDoc system (Biotechnology Laboratory, Neiker, Spain).

Table 10. Oligonucleotide sequences used for amplification of Anaplasma phagocytophilum, Coxiella burnetii and Rickettsia africae targeted genes.

\begin{tabular}{|c|c|c|c|c|c|}
\hline Pathogen & Target Genes & Primer Sequences & $\begin{array}{l}\text { Product Size } \\
\text { (bp) }\end{array}$ & $\begin{array}{l}\text { Annealing } \\
\text { Temp }\left({ }^{\circ} \mathrm{C}\right)\end{array}$ & Reference \\
\hline $\begin{array}{c}\text { Anaplasma } \\
\text { phagocytophilum }\end{array}$ & 16S rRNA & $\begin{array}{c}\text { EHR521F: } \\
\text { 5'-TGTAGGCGGTTCGGTAAGTTAAAG-3' } \\
\text { EHR747R: } \\
\text { 5'-GCACTCATCGTTTACAGCGTG-3' }\end{array}$ & 250 & 60 & [51] \\
\hline Coxiella burnetii & IS1111 transposase & $\begin{array}{c}\text { Trans1-F: } \\
\text { 5'-TATGTATCCACCGTAGCCAGTC-3' } \\
\text { Trans2-R: } \\
\text { 5'-CCCAACAACACCTCCTTATTC-3' }\end{array}$ & 687 & 60 & [52] \\
\hline Rickettsia africae & gltA & $\begin{array}{c}\text { CS-78: } \\
\text { 5'-GCAAGTATCGGTGAGGATGTAAT-3' } \\
\text { CS-323: } \\
\text { 5'-GCTTCCTTAAAATTCAATAAATCAGGAT-3' }\end{array}$ & 401 & 55 & [53] \\
\hline
\end{tabular}

\subsection{Sequencing, Basic Local Alignment Search Tool (BLAST) and Phylogenetic Analysis}

The PCR amplicons were sent to (Inqaba Biotech, Pretoria, South Africa) for purification and sequencing. To confirm sequences obtained from all PCR analysis, nucleotide BLAST (BLASTn) was used (www.ncbi.nlm.nih.gov/blast/, accessed on 16 May 2020). The gene sequences with $80-100 \%$ similarity match scores were considered as significant. The gene sequences were aligned using Clustal $\mathrm{W}$, using multiple alignments under default parameters in MEGA X software [54]. Thereafter, the aligned sequences were trimmed to remove uneven ends from the aligned sequences. The trimmed alignment was subsequently transferred to MEGA X for Maximum Likelihood (ML) analyses. Phylogenetic 
analysis was used to interrogate the relationship between the sequences from pathogens identified in this study with other pathogen sequences (reference sequences obtained from GenBank) and to confirm the identities of our pathogen sequences.

\subsection{Statistical Analyses}

The prevalence of each pathogen species was represented and summarised in tables. A descriptive test was used to determine the difference at $p \geq 0.05$ (Pearson Chi-square value, asymptotic significance 2-sided) for the prevalence of Anaplasma spp, C. burnetii and $R$. africae zoonotic pathogens among tick species. The regression test was used to test if the presence of the pathogen is dependent on tick species using binary logistic statistical analysis. Thereafter, a correlation test was conducted to determine the influence of pathogens on each other using bivariate statistical test. The IBM SPSS software (Version 27, 2020) was used for the analyses.

Supplementary Materials: The following are available online at https:/ / www.mdpi.com/article/ 10.3390/pathogens10091186/s1, Table S1: Tick species collected from domestic animals and districts sampled.

Author Contributions: S.I.C.M.-S., conducted laboratory experiments and made the first draft of the manuscript; O.T.Z. and O.M.M.T., conceptualised, supervised and revised the manuscript; M.J.R.M., collected tick samples. All authors have read and agreed to the published version of the manuscript.

Funding: This research was funded by the National Research Foundation (NRF) Incentive Funding for Rated Researchers (GUN94187 and GUN118949), made available to OMMT, and by Thuthuka Funding Instruments (TTK170411226583), made available to OTZ. The APC was funded by OTZ. The Grant holder acknowledges that opinions, findings and conclusions or recommendations expressed in any publication generated by the NRF supported research is that of the author(s) and that the NRF accepts no liability whatsoever in this regard.

Institutional Review Board Statement: Not applicable.

Informed Consent Statement: Not applicable.

Data Availability Statement: Not applicable.

Acknowledgments: We thank animal owners for their cooperation. This study was made possible.

Conflicts of Interest: The authors declare that they have no competing conflict of interest.

\section{References}

1. El-Ashker, M.; Hotzel, H.; Gwida, M. Molecular biological identification of Babesia, Theileria, and Anaplasma species in cattle in Egypt using PCR assays, gene sequence analysis and a novel DNA microarray. Vet. Parasitol. 2015, 207, 329-334. [CrossRef]

2. Bilgic, H.B.; Karagenc, T.; Simuunza, M.; Shiels, B.; Tait, A.; Eren, H.; Weir, W. Development of a multiplex PCR assay for simultaneous detection of Theileria annulata, Babesia bovis and Anaplasma marginale in cattle. Exp. Parasitol. 2013, 133, $222-229$. [CrossRef]

3. Chitanga, S.; Gaff, H.; Mukaratirwa, S. Tick-borne pathogens of potential zoonotic importance in the southern African Region. J. S. Afr. Vet. Assoc. 2014, 85, 1084. [CrossRef] [PubMed]

4. Marcelino, I.; de Almeida, A.M.; Ventosa, M.; Pruneau, L.; Meyer, D.F.; Martinez, D.; Lefrancois, T.; Vachiery, N.; Coelho, A.V. Tick-borne diseases in cattle: Applications of proteomics to develop new generation vaccines. J. Proteom. 2012, 75, 4232-4250. [CrossRef] [PubMed]

5. Mtshali, K.; Khumalo, Z.; Nakao, R.; Grab, D.J.; Sugimoto, C.; Thekisoe, O. Molecular detection of zoonotic tick-borne pathogens from ticks collected from ruminants in four South African provinces. J. Bacteriol. 2015, 77, 1573-1579. [CrossRef]

6. Lorusso, V.; Wijnveld, M.; Majekodunmi, A.O.; Dongkum, C.; Fajinmi, A.; Dogo, A.G.; Thrusfield, M.; Mugenyi, A.; Vaumourin, E.; Igweh, A.C.; et al. Tick-borne pathogens of zoonotic and veterinary importance in Nigerian cattle. Parasites Vectors $2016,9,217$. [CrossRef] [PubMed]

7. Mtshali, K.; Nakao, R.; Sugimoto, C.; Thekisoe, O. Occurrence of Coxiella burnetii, Ehrlichia canis, Rickettsia species and Anaplasma phagocytophilum-like bacterium in ticks collected from dogs and cats in South Africa. J. S. Afr. Vet. Assoc. 2017, 88, e1-e6. [CrossRef]

8. Aktas, M.; Özübek, S. Bovine anaplasmosis in Turkey: First laboratory confirmed clinical cases caused by Anaplasma phagocytophilum. Vet. Microbiol. 2015, 178, 246-251. [CrossRef] [PubMed] 
9. Dumler, J.S.; Choi, K.-S.; Garcia-Garcia, J.C.; Barat, N.S.; Scorpio, D.G.; Garyu, J.W.; Grab, D.J.; Bakken, J.S. Human Granulocytic Anaplasmosis and Anaplasma phagocytophilum. Emerg. Infect. Dis. 2005, 11, 1828-1834. [CrossRef]

10. Adaszek, L.; Winiarczyk, S. Identification of Anaplasma spp. Rickettsia isolated from horses from clinical disease cases in Poland. Zoonoses Public Health 2011, 58, 514-518. [CrossRef]

11. Rymaszewska, A.; Grenda, S. Bacteria of the genus Anaplasma-Characteristics of Anaplasma and their vectors: A review. Vet. Med. 2008, 53, 573-584. [CrossRef]

12. Inokuma, H.; Oyamada, M.; Kelly, P.J.; Jacobson, L.A.; Fournier, P.E.; Itamoto, K.; Okuda, M.; Brouqui, P. Molecular detection of a new Anaplasma species closely related to Anaplasma phagocytophilum in canine blood from South Africa. J. Clin. Microbiol. 2005, 43, 2934-2937. [CrossRef] [PubMed]

13. Salifu, S.P.; Bukari, A.A.; Frangoulidis, D.; Wheelhouse, N. Current perspectives on the transmission of Q fever: Highlighting the need for a systematic molecular approach for a neglected disease in Africa. Acta Trop. 2019, 193, 99-105. [CrossRef] [PubMed]

14. Mediannikov, O.; Fenollar, F.; Socolovschi, C.; Diatta, G.; Bassene, H.; Molez, J.F.; Sokhna, C.; Trape, J.F.; Raoult, D. Coxiella burnetii in humans and ticks in rural Senegal. PLoS Negl. Trop. Dis. 2010, 4, e654. [CrossRef]

15. Rodolakis, A. Q Fever in Dairy Animals. Ann. N. Y. Acad. Sci. 2009, 1166, 90-93. [CrossRef] [PubMed]

16. Maurin, M.; Raoult, D. Q Fever. Clin. Microbiol. Rev. 1999, 12, 518-553. [CrossRef] [PubMed]

17. Guatteo, R.; Seegers, H.; Taurel, A.F.; Joly, A.; Beaudeau, F. Prevalence of Coxiella burnetii infection in domestic ruminants: A critical review. Vet. Microbiol. 2011, 149, 1-16. [CrossRef] [PubMed]

18. Moodie, C.E.; Thompson, H.A.; Meltzer, M.I.; Swerdlow, D.L. Prophylaxis after exposure to Coxiella burnetii. Emerg. Infect. Dis. 2008, 14, 1558-1566. [CrossRef]

19. Psaroulaki, A.; Hadjichristodoulou, C.; Loukaides, F.; Soteriades, E.; Konstantinidis, A.; Papastergiou, P.; Ioannidou, M.C.; Tselentis, Y. Epidemiological study of Q fever in humans, ruminant animals, and ticks in Cyprus using a geographical information system. Eur. J. Clin. Microbiol. Infect. Dis. 2006, 25, 576-586. [CrossRef]

20. Cazorla, C.; Socolovschi, C.; Jensenius, M.; Parola, P. Tick-borne diseases: Tick-borne spotted fever rickettsioses in Africa. Infect. Dis. Clin. N. Am. 2008, 22, 531-544. [CrossRef]

21. Parola, P.; Paddock, C.D.; Socolovschi, C.; Labruna, M.B.; Mediannikov, O.; Kernif, T.; Abdad, Y.M.; Stenos, J.; Bitam, I.; Fournier, P.E.; et al. Update on Tick-Borne Rickettsioses around the World: A Geographic Approach. Clin. Microbiol. Rev. 2013, 26, 657-702. [CrossRef] [PubMed]

22. Althaus, F.; Greub, G.; Raoult, D.; Genton, B. African tick-bite fever: A new entity in the differential diagnosis of multiple eschars in travelers. Description of five cases imported from South Africa to Switzerland. Int. J. Infect. Dis. 2010, 14S, e274-e276. [CrossRef]

23. Ndip, L.M.; Titanji, V.P.K.; Ndip, R.N.; McBride, J.W.; Bouyer, D.H.; Walker, D.H.; Fokam, E.B. Detection of Rickettsia africae in patients and ticks along the coastal region of Cameroon. Am. J. Trop. Med. Hyg. 2004, 71, 363-366. [CrossRef] [PubMed]

24. Rutherford, J.S.; Macaluso, K.R.; Smith, N.; Zaki, S.R.; Paddock, C.D.; Davis, J.; Peterson, N.; Azad, A.F.; Rosenburg, R. Fatal Spotted Fever Rickettsiosis, Kenya. Emerg. Infect. Dis. 2004, 10, 910-913. [CrossRef]

25. Portillo, A.; Pérez-Martínez, L.; Santibáñez, S.; Blanco, J.R.; Ibarra, V.; Oteo, J.A. Short Report: Detection of Rickettsia africae in Rhipicephalus (Boophilus) decoloratus ticks from the Republic of Botswana, South Africa. Am. J. Trop. Med. Hyg. 2007, 77, 376-377. [CrossRef]

26. Caruso, G.; Zasio, C.; Guzzo, F.; Granata, C.; Mondardini, V.; Guerra, E.; Macri, E.; Benedetti, P. Outbreak of African tick-bite fever in six Italian tourists returning from South Africa. Eur. J. Clin. Microbiol. Infect. Dis. 2002, 21, 133-136. [CrossRef]

27. Horak, I.G.; Heyne, H.; Halajian, A.; Booysen, S.; Smit, W.J. Parasites of domestic and wild animals in South Africa. L. Ixodid ticks infesting horses and donkeys. Onderstepoort J. Vet. Res. 2017, 84, e1-e6. [CrossRef]

28. Spickett, A.M.; Heyne, I.H.; Williams, R. Survey of the livestock ticks of the North West province, South Africa. Onderstepoort J. Vet. Res. 2011, 78, 305. [CrossRef]

29. Horak, I.G.; Nyangiwe, N.; de Matos, C.; Neves, L. Species composition and geographic distribution of ticks infesting cattle, goats and dogs in a temperate and in a subtropical region of south-east Africa. Onderstepoort J. Vet. Res. 2009, 76, 263-276. [CrossRef]

30. Yawa, M.; Nyangiwe, N.; Kadzere, C.T.; Muchenje, V.; Mpendulo, T.C.; Marufu, M.C. In search of the Rhipicephalus (Boophilus) microplus in the western-central regions of the Eastern Cape Province, South Africa. Ticks Tick Borne Dis. 2019, 10, 564-567. [CrossRef] [PubMed]

31. Horak, I.G.; Jordaan, A.J.; Nel, P.J.; van Heerden, J.; Heyne, H.; van Dalen, E.M. Distribution of endemic and introduced tick species in Free State Province, South Africa. J. S. Afr. Vet. Assoc. 2015, 86, 1255. [CrossRef] [PubMed]

32. Baron, S.; van der Merwe, N.A.; Maritz-Olivier, C. The genetic relationship between R. microplus and R. decoloratus ticks in South Africa and their population structure. Mol. Phylogenet. Evol. 2018, 129, 60-69. [CrossRef]

33. Barker, S.C.; Walker, A.R. Ticks of Australia. The species that infest domestic animals and humans. Zootaxa 2014, 1, 1-144. [CrossRef]

34. Matjila, P.T.; Leisewitz, A.L.; Jongejan, F.; Penzhorn, B.L. Molecular detection of tick-borne protozoal and ehrlichial infections in domestic dogs in South Africa. Vet. Parasitol. 2008, 155, 152-157. [CrossRef] [PubMed]

35. Halajian, A.; Palomar, A.M.; Portillo, A.; Heyne, H.; Luus-Powell, W.J.; Oteo, J.A. Investigation of Rickettsia, Coxiella burnetii and Bartonella in ticks from animals in South Africa. Ticks Tick Borne Dis. 2016, 7, 361-366. [CrossRef] 
36. Khoo, J.J.; Lim, F.S.; Chen, F.; Phoon, W.H.; Khor, C.S.; Pike, B.L.; Chang, L.Y.; AbuBakar, S. Coxiella detection in ticks from wildlife and livestock in Malaysia. Vector Borne Zoonotic Dis. 2016, 16, 744-751. [CrossRef] [PubMed]

37. Gummow, B.; Poerstamper, N.; Herr, S. The incidence of Coxiella burnetii antibodies in cattle in the Transvaal. Onderstepoort J. Vet. Res. 1987, 54, 569-571. [PubMed]

38. Qiu, Y.; Nakao, R.; Namangala, B.; Sugimoto, C. First genetic detection of Coxiella burnetii in Zambian livestock. Am. J. Trop. Med. Hyg. 2013, 89, 518-519. [CrossRef]

39. Vanderburg, S.; Rubach, M.P.; Halliday, J.E.; Cleaveland, S.; Reddy, E.A.; Crump, J.A. Epidemiology of Coxiella burnetii infection in Africa: A One Health systematic review. PLoS Negl. Trop. Dis. 2014, 8, e2787. [CrossRef] [PubMed]

40. Seo, M.G.; Lee, S.H.; Ouh, I.O.; Lee, G.H.; Goo, Y.K.; Kim, S.; Kwon, O.D.; Kwak, D. Molecular detection and genotyping of Coxiella-like endosymbionts in ticks that infest horses in south Korea. PLoS ONE 2016, 11, e0165784. [CrossRef]

41. Frean, J.; Grayson, W. South African Tick Bite Fever: An Overview. Dermatopathology 2019, 6, 70-76. [CrossRef]

42. Roch, N.; Epauland, O.; Pelloux, I.; Pavese, P.; Brion, J.-P.; Raoult, D.; Maurin, M. African tick bite fever in elderly patients: 8 cases in French tourists returning from South Africa. Clin. Infect. Dis. 2008, 47, e28-e35. [CrossRef] [PubMed]

43. Angerami, R.N.; Krawczak, F.S.; Nieri-Bastos, F.A.; Santos, F.; Medorima, C.; Resende, M.R.; Labruna, M.B. First report of African tick-bite fever in a South American traveler. SAGE Open Med. Case Rep. 2018, 6, 2050313X18775301. [CrossRef] [PubMed]

44. Macaluso, K.R.; Davis, J.; Alam, U.; Korman, A.; Rutherford, J.S.; Rosenburg, R.; Azad, A.F. Spotted fever group rickettsiae in ticks from the Masai Mara region of Kenya. Am. J. Trop. Med. Hyg. 2003, 68, 551-553. [CrossRef] [PubMed]

45. Jongejan, F.; Uilenberg, G. The global importance of ticks. Parasitology 2004, 129, 2872. [CrossRef]

46. Latif, A.A. Illustrated Guide to Identification of African Tick Species. Ticks and Tick-Borne Diseases Monograph, 2nd ed.; Agri Connect (PTY) Ltd.: Pretoria, South Africa, 2013; Volume 2, p. 79.

47. Madder, M.; Horak, I.G.; Stoltsz, H. Ticks: Tick Identification. South Africa: Creatives Commons Attribution Lisence. 58. 2013.

48. Mlangeni, M.A. Molecular Epidemiology of Dourine, Equine Piroplasmosis and Ehrlichiosis from Donkeys and Horses in South Africa. Master's Thesis, Unit of Environmental Science and Management, North-West Univeristy, Vanderbijlpark, South Africa, September 2016.

49. Walker, A.R.; Bouattour, A.; Camicas, J.-L.; Estrada-Pena, A.; Horak, I.G.; Latif, A.A.; Pegram, R.G.; Preston, P.M. Ticks of Domestic Animals in Africa: A Guide to Identification of Species; Bioscience Reports: Edinburgh, UK, 2003; p. 227.

50. Mahlobo, S.I.; Zishiri, O.T. A descriptive study of parasites detected in ticks of domestic animals in Lesotho. Vet. Parasitol. Reg. Stud. Rep. 2021, 25, 100611.

51. Hodzic, E.; Fish, D.; Maretziki, C.M.; de Silva, A.M.; Feng, S.; Barthold, S.W. Acquisition and Transmission of the Agent of Human Granulocytic Ehrlichiosis by Ixodes scapularis Ticks. J. Clin. Microbiol. 1998, 36, 3574-3578. [CrossRef]

52. Mares-Guia, M.A.; Rozental, T.; Guterres, A.; Gomes, R.; Almeida, D.N.; Moreira, N.S.; Barreira, J.D.; Favacho, A.R.; Santana, A.L.; Lemos, E.R. Molecular identification of the agent of $Q$ fever-Coxiella burnetii-In domestic animals in State of Rio de Janeiro, Brazil. Rev. Soc. Bras. Med. Trop. 2014, 47, 231-234. [CrossRef]

53. Labruna, M.B.; Whitworth, T.; Horta, M.C.; Bouyer, D.H.; McBride, J.W.; Pinter, A.; Popov, V.; Gennari, S.M.; Walker, D.H. Rickettsia species infecting Amblyomma cooperi ticks from an area in the state of Sao Paulo, Brazil, where Brazilian spotted fever is endemic. J. Clin. Microbiol. 2004, 42, 90-98. [CrossRef]

54. Kumar, S.; Stecher, G.; Li, M.; Knyaz, C.; Tamura, K. MEGA X: Molecular Evolutionary Genetics Analysis across Computing Platforms. Mol. Biol. Evol. 2018, 35, 1547-1549. [CrossRef] 